\title{
Bath administration of the quinoline antibiotic flumequine to brown trout Salmo trutta and Atlantic salmon S. salar
}

\author{
P. O'Grady, M. Moloney, P. R. Smith \\ Department of Microbiology, University College, Galway, Ireland
}

\begin{abstract}
Administration of flumequine to brown trout Salmo trutta and Atlantic salmon Salmo salar, using bath treatments, resulted in significant serum levels of the antibiotic. Bath concentrations of 50 , 100 and $500 \mathrm{ppm}$ were tested for up to $5 \mathrm{~h}$. Temperature, $\mathrm{pH}$, and calcium hardness of the bath water were all found to influence serum levels achieved, as did the level of the drug in the bath. Following bath treatment, serum levels of flumequine greater than the minimum inhibitory concentrations for most susceptible fish pathogens were maintained for up to $14 \mathrm{~d}$. Flumequine serum levels eliciting a toxic response in treated fish were determined. The efficacy of flumequine bath treatments in the control of furunculosis, caused by Aeromonas salmonicida, has been established and its application as both a prophylactic and a chemotherapeutic method for the control of bacterial infections is proposed.
\end{abstract}

\section{INTRODUCTION}

Flumequine (9-fluoro-6,7-dihydro-5-methyl-1-oxo$1 \mathrm{H}, 5 \mathrm{H}$-benzo-quinolizine-2-carboxylic acid) is a member of the halogenated quinoline carboxylic acid group of antibacterial agents with antimicrobial activity against a wide range of Gram-negative bacteria (Edelson et al. 1977, Neuman 1978, Lemeland et al. 1981). A structural analog of nalidixic acid and oxolinic acid, it has been recommended for the treatment of urinary tract infections (Rohlfing et al. 1976. Steer et al. 1981) and enteric infections (Rohlfing et al. 1977) in humans. It has however been primarily utilised in veterinary medicine for treating domestic animals (Benothame 1979, Ziv et al. 1986).

Both flumequine and oxolinic acid have been routinely administered to farmed fish as both prophylactic and chemotherapeutic agents, principally against systemic bacterial infections, especially furunculosis, caused by Aeromonas salmonicida (Michel et al. 1980, Austin et al. 1983, Scallan \& Smith 1985) and enteric red mouth disease, caused by Yersinia ruckeri (Rodgers \& Austin 1983). A third quinoline antibiotic, piromidic acid, has been recommended as a safe and effective compound for the treatment of bacterial infections in goldfish Carassius aurata and eel Anguilla japonica (Katae et al. 1979) and against furunculosis in ayu Plecoglossus altivelis (Sano unpubl.).

The widespread use of flumequine for the treatment of bacterial infections in farmed fish is due mainly to its relatively low minimum inhibitory concentration (MIC) for most susceptible fish pathogens (Ledo et al. 1987. O'Grady et al. 1987) and effective systemic distribution when administered orally via medicated food (Chevalier et al. 1981). However, diseased fish tend to be anorexic, and this gives rise to a situation where only clinically healthy individuals within a population (i.e. those that are still feeding) are likely to be protected by the oral administration of antibiotics. This has led to the examination of alternative modes of administration of these antibiotics.

Intraperitoneal injection (i.p.) represents the most effective, though laborious, means of administering an accurate therapeutic dose of flumequine to an individual. However, the stress that this method can impose on diseased fish renders it inappropriate as a method of chemotherapy. Nevertheless, this method has been used successfully for the elimination of Aeromonas salmonicida from asymptomatic carriers in populations of Atlantic salmon prior to their transfer from freshwater to seawater (Scallan \& Smith 1985).

In an attempt to achieve high systemic flumequine 
levels comparable to those obtained with an i.p. injection while avoiding its attendant stress, we studied the feasibility of administering flumequine by the bath method. Our objective was to develop a prophylactic and chemotherapeutic treatment for the control of bacterial infections of farmed fish.

\section{MATERIALS AND METHODS}

Experimental fish. The fish used in these experiments were either brown trout Salmo trutta (average weight $28.72 \mathrm{~g}$ ) or Atlantic salmon Salmo salar (average weight $28.43 \mathrm{~g}$ ). The brown trout were held in $500 \mathrm{l}$ flow-through tanks at ambient temperature $\left(7\right.$ to $\left.12^{\circ} \mathrm{C}\right)$ untii required. With one exception experimentai fish were not fed for $3 \mathrm{wk}$ before use, nor during experiments. The exception was an experiment, described below, to test the effect of feeding on drug absorption. The pre-smolt salmon were transported to this laboratory from a fish hatchery where a clinical outbreak of furunculosis was in its second week. The 5001 flowthrough tanks used for holding the fish and the $50 \mathrm{l}$ flow-through tanks to which test fish were removed after flumequine bath administrations were supplied with dechlorinated water ( $\mathrm{pH} 7.1$ to $7.8 ; 132$ to $173 \mathrm{mg}$ $\mathrm{l}^{-1} \mathrm{CaCO}_{3} ; 78$ to $89 \mathrm{mg} \mathrm{l}^{-1}$ total alkalinity). Distilled water ( $\mathrm{pH} 6.5$ to $6.7 ; 1$ to $2 \mathrm{mg} \mathrm{l}^{-1} \mathrm{CaCO}_{3} ; 10$ to $12 \mathrm{mg}$ $\mathrm{l}^{-1}$ total alkalinity) was used in all bath administrations. At all times both the control and treated groups of fish were maintained in Aeromonas salmonicida-free water (Scallan 1983).

Bath administrations. All of the bath administrations carried out in the laboratory were run in $10 \mathrm{l}$ plastic buckets containing $4 \mathrm{l}$ of the antibiotic solution or in $100 \mathrm{l}$ plastic tanks containing various volumes of the antibiotic solution. The antibiotic solution was prepared by diluting flumequine (Flumisol-10\%, Riker Labs., France) in distilled water to the final desired concentration of 50,100 , or $500 \mathrm{ppm}$. If necessary, the $\mathrm{pH}$ was then adjusted to the desired level with $1 \mathrm{~N}$ $\mathrm{NaOH}$ (BDH Chemicals Ltd., Poole, England) for a particular bath treatment. The bath solutions were aerated and were placed in a water bath to attain the desired temperature for each particular bath treatment. Calcium hardness levels were adjusted by the addition of calcium oxide (BDH Chemicals Ltd) to the antibiotic baths. The calcium levels were determined by the standard EDTA titration method and expressed as mg $1^{-1} \mathrm{CaCO}_{3}$ (Franson et al. 1974).

Test fish were held at the same temperature as the bath for $24 \mathrm{~h}$ before being used in each laboratory bath treatment ( 1 fish $1^{-1}$ antibiotic solution). Serum samples from treated fish were obtained by removing blood from the caudal vein following anaesthesia with ben- zocaine (50 ppm, Sigma Ltd, Poole, England). Serum. samples were also taken from untreated fish as controls. The blood was allowed to stand at room temperature for $1 \mathrm{~h}$ and was then held overnight at $4{ }^{\circ} \mathrm{C}$ to allow clotting to proceed. Blood samples were centrifuged and the serum removed and stored at $-20^{\circ} \mathrm{C}$. Bioassays, as described below, were carried out within $1 \mathrm{wk}$ of bleeding.

The flumequine assay used was a standard agar cupplate diffusion assay following the guidelines of Reeves \& Bywater (1976). A tryptone soya broth (Oxoid Ltd, Basingstoke, England) culture of Vibrio anguillarium 775 , with $1 \%$ added $\mathrm{NaCl}$ and an optical density of 0.1 at $540 \mathrm{~nm}$, was used ( $5 \mathrm{ml}$ ) to seed $200 \mathrm{ml}$ of tryptone soya agar (TSA, Oxoid) plus $1 \% \mathrm{NaCl}$. Five doubling dilutions of a filumequine stock solution ranging from either 48 to $3 \mu \mathrm{g} \mathrm{ml}^{-1}, 32$ to $2 \mu \mathrm{g} \mathrm{ml}^{-1}$, or 16 to $1 \mu \mathrm{g} \mathrm{ml} \mathrm{m}^{-1}$ were used in each plate. Test and control fish sera were added to 1, 2, or 3 wells. A second flumequine stock solution was used to prepare 2 control concentrations. The plates were incubated at $30^{\circ} \mathrm{C}$ overnight and zones of inhibition of growth around the wells were measured. For all assays, a standard curve was computed for each test plate by regression analysis. The concentration of flumequine in the test sera was calculated and corrected for error by reference to the controls. A correlation coefficient was calculated for each curve and all were shown to be highly significant at the $99 \%$ confidence level ( $r=0.998, p<0.001)$.

Retention times of flumequine serum levels. Fiftytwo brown trout were given $50 \mathrm{ppm}$ flumequine bath treatment at $11^{\circ} \mathrm{C}$ for $3 \mathrm{~h}$ in distilled water. Four fish were removed at $0 \mathrm{~h}$, and 4 more at $1 \mathrm{~h}$ and at $3 \mathrm{~h}$ during the bath treatment. Blood samples were taken and flumequine serum levels determined.

At the termination of the bath treatment the remaining 40 fish were removed to a $50 \mathrm{l}$ flow-through tank at ambient temperature $\left(7\right.$ to $\left.10^{\circ} \mathrm{C}\right)$ for $14 \mathrm{~d}$. Four fish were removed at each of the following times posttreatment: $1 \mathrm{~h}, 3 \mathrm{~h}, 5 \mathrm{~h}, 8 \mathrm{~h}, 12 \mathrm{~h}, 1 \mathrm{~d}, 3 \mathrm{~d}, 6 \mathrm{~d}, 10 \mathrm{~d}$, and $14 \mathrm{~d}$. Blood samples were taken from these fish and flumequine serum levels determined.

Forty brown trout were anesthetised with benzocaine (50 ppm) and injected i.p. with a $3 \%$ injectable flumequine suspension (Flumiquil, Riker Labs.) diluted in $0.85 \%$ saline to give a dosage of $30 \mathrm{mg} \mathrm{kg}^{-1}$ fish. The fish were then maintained and serum levels determined in the same way as for bath-treated fish.

Effect of feeding on flumequine absorption. Two groups of 20 brown trout were held in $500 \mathrm{l}$ flowthrough tanks at ambient temperature $\left(11\right.$ to $\left.12^{\circ} \mathrm{C}\right)$ for $21 \mathrm{~d}$. One group was fed at a rate of $1 \%$ body weight per day whilst the second group received no feed. On the 21 st day both groups were placed in a flumequine bath solution of $50 \mathrm{ppm}$, at $11^{\circ} \mathrm{C}$ and $\mathrm{pH} 7$, in distilled 
water for $1 \mathrm{~h}$. The 2 groups were kept apart by means of a perforated screen. At the termination of the bath treatment, blood samples were taken from 10 fish of each group and flumequine serum levels determined.

Toxicity of bath-administered flumequine. Forty brown trout were given a flumequine bath treatment of $50 \mathrm{ppm}$ at $11^{\circ} \mathrm{C}$ and $\mathrm{pH} 6.5(40 \mathrm{l})$. At the first sign of toxicity (onset of lethargy) 10 fish were sampled to determine flumequine serum levels. At the same time 10 fish were removed to a $50 \mathrm{l}$ flow-through tank at ambient temperature $\left(12^{\circ} \mathrm{C}\right)$ where their recovery was monitored. When the remaining 20 fish in the flumequine bath lost their equilibrium, 10 fish were sampled to determine flumequine serum levels and the remaining 10 were removed to a $50 \mathrm{l}$ flow-through tank where their recovery was monitored.

Bath treatment of salmon suffering from furunculosis. Three hundred pre-smolt Atlantic salmon from a population undergoing a clinical outbreak of furunculosis were transported to this laboratory from a local fish hatchery and maintained in a $500 \mathrm{l}$ flow-through tank at ambient temperature $\left(12^{\circ} \mathrm{C}\right)$. Two d later, 200 fish received a flumequine bath treatment of $50 \mathrm{ppm}$ for $3 \mathrm{~h}$ at $11^{\circ} \mathrm{C}$ and $\mathrm{pH} 7$ in distilled water (100 l). Immediately after treatment, 4 fish were bled to determine the flumequine serum levels achieved. The remainder of the group were returned to a $500 \mathrm{l}$ flow-through tank at ambient temperature $\left(12.5^{\circ} \mathrm{C}\right)$. Two d post-treatment the fish were stressed by an intramuscular injection of prednisolone acetate (PA, Boots PLC, Nottingham, England) at a dosage of $20 \mathrm{mg} \mathrm{kg}^{-1}$ fish. The stressed fish were than held in a $150 \mathrm{l}$ tank at $18^{\circ} \mathrm{C}$ for $14 \mathrm{~d}$. The remaining 100 fish were used as an untreated control group. The control fish were stressed in the same manner and at the same time as the treated fish.

Kidney material from dead fish was streaked on TSA and incubated at $22^{\circ} \mathrm{C}$ for $48 \mathrm{~h}$. On isolation of colonies producing a brown diffusable pigment within $48 \mathrm{~h}$, mortalities were attributed to Aeromonas salmonicida. At the termination of the stress, test kidney material of the surviving fish from both the treated and the control groups was tested for the presence of $A$. salmonicida as described above. The sensitivity of the $A$. salmonicida isolates to both flumequine and oxolinic acid was tested by the standard Kirby-Bauer method (Brown \& Blowers 1978).

\section{RESULTS}

\section{Effect of flumequine concentration on absorption}

Serum levels achieved in brown trout by a bath administration of flumequine at various concentrations at $11^{\circ} \mathrm{C}$ and $\mathrm{pH} 7$ are presented in Fig. 1. At a concentration of $500 \mathrm{ppm}$, high serum flumequine levels were

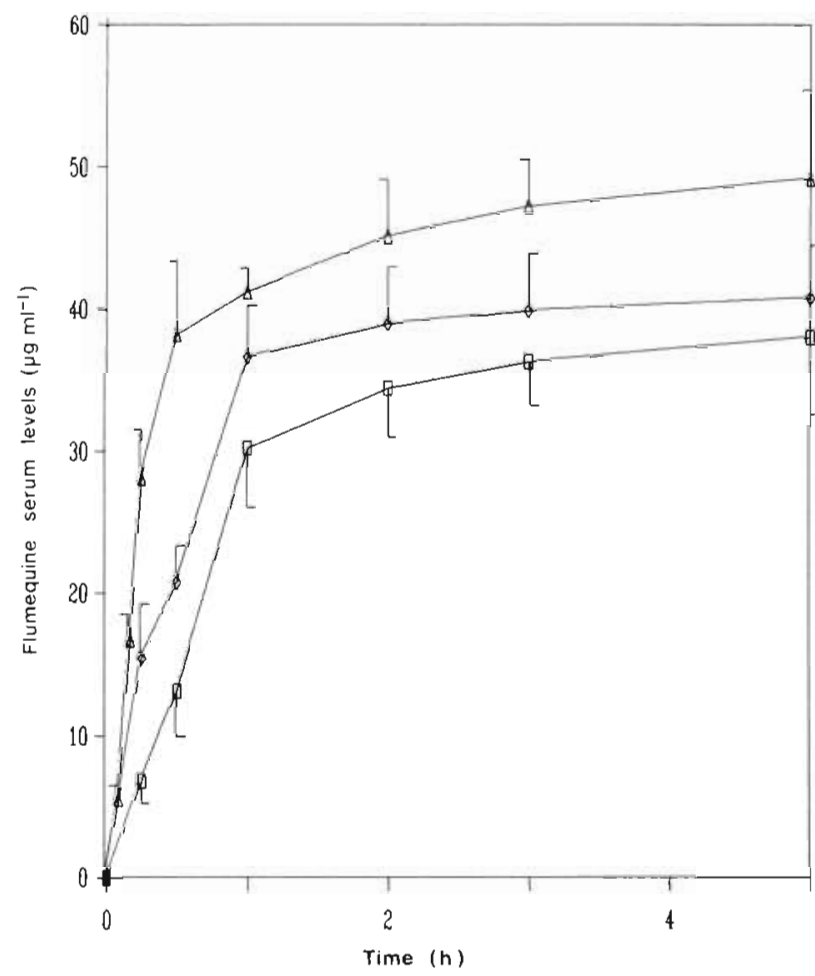

Fig. 1. Salmo trutta. Effect of concentration and duration of treatment of flumequine absorption. Distilled water at $11^{\circ} \mathrm{C}$ and $\mathrm{pH} 7.0$ with (ㄷ) $50 \mathrm{ppm}$ flumequine; ( $) 100 \mathrm{ppm}$ flumequine; (ه) 500 ppm flumequine

rapidly achieved. The rate of absorption was greatest in the first $30 \mathrm{~min}$, with serum levels of $38 \mu \mathrm{g} \mathrm{ml}^{-1}( \pm 5.2)$ being attained. Subsequently, the rate of absorption declined, with serum levels reaching $49 \mu \mathrm{g} \mathrm{ml}^{-1}$ ( \pm 6.1 ) after $5 \mathrm{~h}$ of treatment. Administration of flumequine at 50 and $100 \mathrm{ppm}$ resulted in similar patterns of drug absorption. In the $100 \mathrm{ppm}$ bath, the initial rate of absorption was rapid, with serum levels of $37 \mu \mathrm{g} \mathrm{ml}^{-1}$ $( \pm 3.7$ ) being achieved after $1 \mathrm{~h}$ of treatment. The rate of absorption subsequently decreased and levels of 41 $\mu \mathrm{g} \mathrm{ml^{-1 }}( \pm 3.8)$ were present after $5 \mathrm{~h}$ of treatment. The $50 \mathrm{ppm}$ bath treatment resulted in serum levels of $30 \mu \mathrm{g}$ $\mathrm{ml}^{-1}\left( \pm 4.2\right.$ ) and $38 \mu \mathrm{g} \mathrm{m} l^{-1}$ ( \pm 5.4 ) following 1 and $5 \mathrm{~h}$ of treatment, respectively.

Bath administration of flumequine at 50 and $100 \mathrm{ppm}$ for $1 \mathrm{~h}$ in distilled water achieved high serum levels with no apparent toxic effects. These baths were therefore used as the standard tests for studying the effect of various parameters on flumequine absorption.

\section{Effect of $\mathrm{pH}$ on absorption}

The effect of $\mathrm{pH}$ on the absorption of flumequine was studied using 50 and $100 \mathrm{ppm}$ baths for $1 \mathrm{~h}$ at $11^{\circ} \mathrm{C}$. Results are presented in Fig. 2. A progressive decline in 


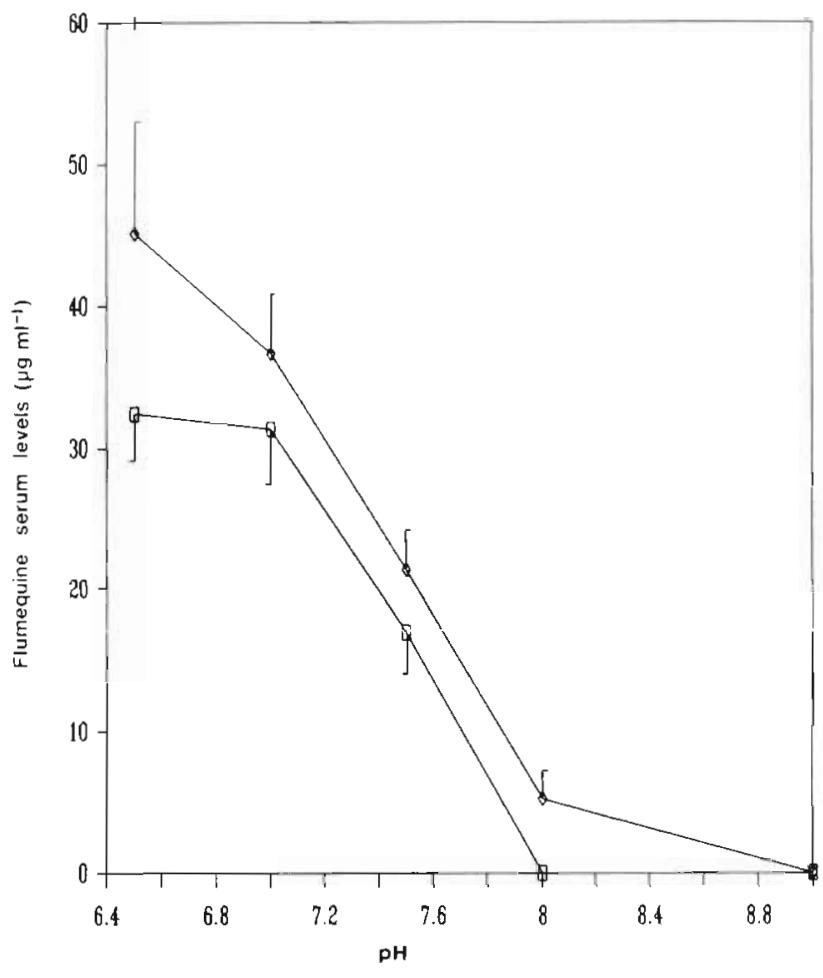

Fig. 2 Salmo trutta. Effect of $\mathrm{pH}$ on the absorption of bathadministered flumequine. Distilled water at $11^{\circ} \mathrm{C}$ with $(\square) 50$ ppm flumequine; (0) 100 ppm flumequine

uptake occurred with increasing $\mathrm{pH}$, with observed levels falling from $35 \mu \mathrm{g} \mathrm{ml}^{-1}\left( \pm 4.3\right.$ ) at pH 7 to $5 \mu \mathrm{g} \mathrm{ml}^{-1}$ $( \pm 2.0)$ at $\mathrm{pH} 8$ for the $100 \mathrm{ppm}$ bath test. No detectable serum levels were observed at pH 9 . A similar result was observed with the $50 \mathrm{ppm}$ bath test where flumequine serum levels fell from $31 \mu \mathrm{g} \mathrm{m} \mathrm{m}^{-1}( \pm 3.9)$ at $\mathrm{pH} 7$ to undetectable levels at $\mathrm{pH} 8$. With both the 50 and the 100 ppm bath treatments at $\mathrm{pH}$ 6.5, flumequine was observed to crystallise out of solution due to its low solubility at acidic $\mathrm{pH}$. A slight toxic effect was observed at $\mathrm{pH} 6.5$ during the $100 \mathrm{ppm}$ treatment where the 4 treated fish appeared lethargic compared to their counterparts in the 50 ppm treatment.

\section{Effect of temperature on absorption}

The effect of temperature on the absorption of flumequine was studied using 50 and 100 ppm baths for $1 \mathrm{~h}$ at $\mathrm{pH} 7$. Results are shown in Fig. 3. In the 50 ppm bath treatment the relationship between serum levels of flumequine and temperature is approximately linear between 3 and $15^{\circ} \mathrm{C}$ with levels of $4 \mu \mathrm{g} \mathrm{ml}^{-1}( \pm 1.2)$ and $38 \mu \mathrm{g} \mathrm{ml} \mathrm{m}^{-1}( \pm 2.6)$ being recorded at these temperatures, respectively. A levelling off in serum levels is seen at $18^{\circ} \mathrm{C}\left(41 \mu \mathrm{g} \mathrm{ml}{ }^{-1}, \pm 2.8\right)$. The $100 \mathrm{ppm}$ bath treatment showed a similar linearity in the absorption-

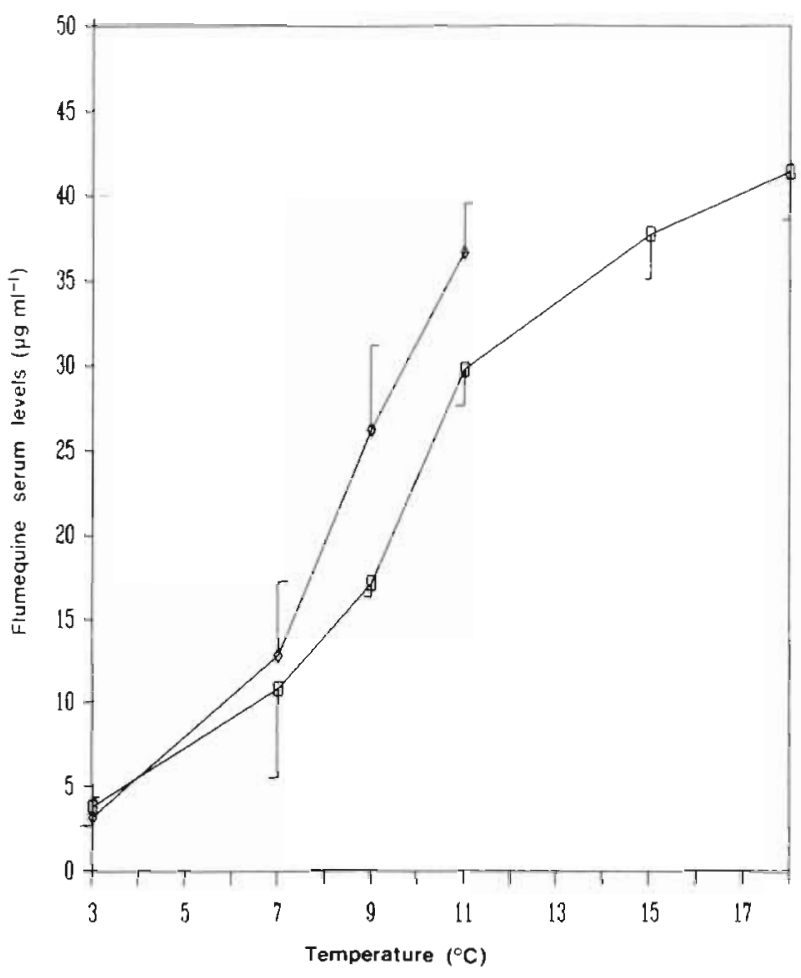

Fig. 3. Salmo trutta. Effect of temperature on the absorption of bath-administered flumequine. Distilled water at $\mathrm{pH} 7.0$ with (ㅁ) $50 \mathrm{ppm}$ flumequine; ( $(0) 100 \mathrm{ppm}$ flumequine

temperature relationship between $3^{\circ} \mathrm{C},(3 \mu \mathrm{g} \mathrm{ml})^{-1}, \pm$ $1.1)$, and $11^{\circ} \mathrm{C},\left(38 \mu \mathrm{g} \mathrm{ml} l^{-1}, \pm 2.9\right)$. However, the levels of absorption were not determined at 15 and $18^{\circ} \mathrm{C}$.

\section{Effect of calcium hardness on absorption}

The effect of various calcium hardness levels (as mg $1^{-1} \mathrm{CaCO}_{3}$ ) on the absorption of flumequine was studied using 50 ppm baths for $1 \mathrm{~h}$ at $\mathrm{pH} 7$ and $11^{\circ} \mathrm{C}$. Results are presented in Fig. 4. Flumequine serum levels of $29 \mathrm{\mu g} \mathrm{ml}^{-1}( \pm 2.1)$ were achieved by the standard bath test in the absence of added calcium. A decrease in flumequine absorption with increasing levels of calcium was most pronounced at calcium levels up to $75 \mathrm{mg} \mathrm{l}^{-1} \mathrm{CaCO}_{3}$. At higher calcium levels, the rate of decrease in flumequine absorption was less pronounced. At $75 \mathrm{mg} \mathrm{l}^{-1} \mathrm{CaCO}_{3}$ serum levels had decreased to $16 \mu \mathrm{g} \mathrm{ml} \mathrm{m}^{-1}( \pm 4.0)$ and thereafter decreased to $10 \mu \mathrm{g} \mathrm{ml}^{-1}( \pm 2.0)$ at $200 \mathrm{mg} \mathrm{l}^{-1} \mathrm{CaCO}_{3}$.

\section{Retention times of flumequine serum levels}

Retention times of bath-administered flumequine in the serum following $3 \mathrm{~h}$ of immersion in $50 \mathrm{ppm}$ of the drug at $\mathrm{pH} 7$ and $11^{\circ} \mathrm{C}$ in distilled water, and following 


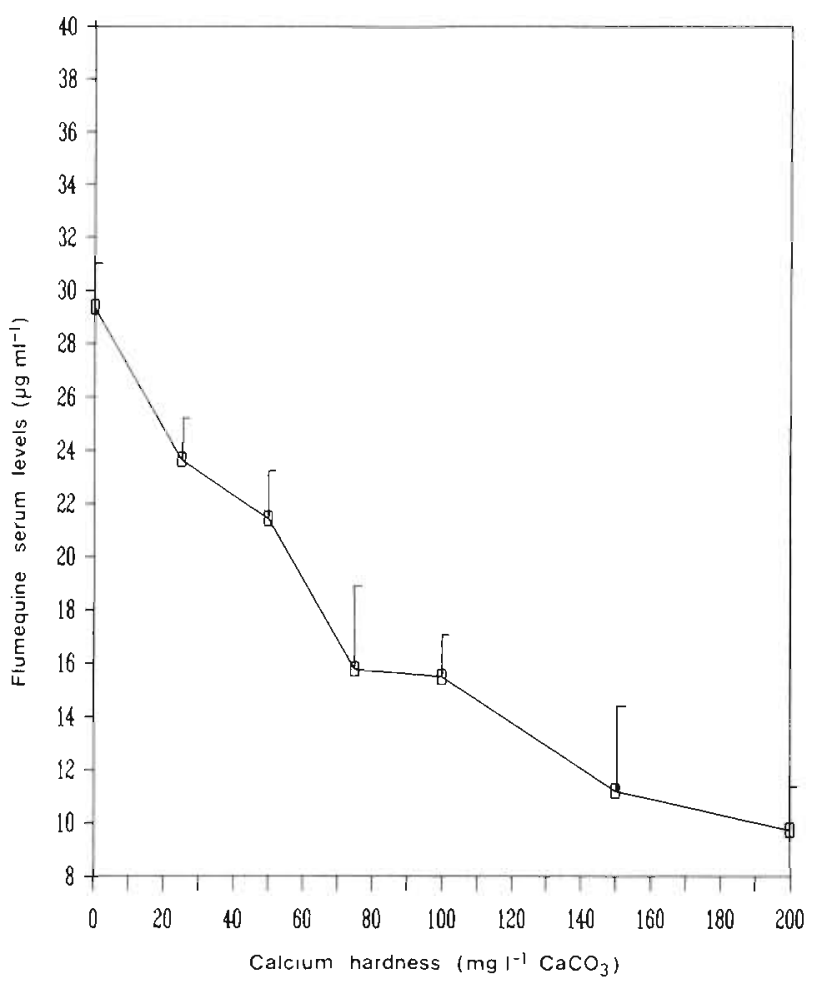

Fig. 4. Salmo trutta. Effect of calcium hardness on the absorption of bath-administered flumequine. Distilled water at $11{ }^{\circ} \mathrm{C}$ and $\mathrm{pH} 7.0$ containing $50 \mathrm{ppm}$ flumequine and various concentrations of calcium

an i.p. injection, are presented in Figs. 5a and b. Bath administration of flumequine resulted in peak serum levels of $43 \mu \mathrm{g} \mathrm{ml}^{-1}$ ( \pm 11.8 which fell to $21 \mu \mathrm{g} \mathrm{ml}^{-1}$ $( \pm 3.1)$ after $24 \mathrm{~h}$ and $11 \mu \mathrm{g} \mathrm{ml} \mathrm{m}^{-1}( \pm 5.2$ after $3 \mathrm{~d})$. Subsequently, the rate of flumequine elimination decreased with serum levels of $1 \mu \mathrm{g} \mathrm{ml}^{-1}( \pm 0.4)$ still being present $14 \mathrm{~d}$ after treatment.

The curve depicting serum retention time following an i.p. injection of $30 \mathrm{mg}$ flumequine $\left(\mathrm{kg}\right.$ fish) ${ }^{-1}$ showed a similar result to that reported by Scallan \& Smith (1985). Peak serum levels of $31 \mu \mathrm{g} \mathrm{m}^{-1}$ ( \pm 3.6 ) were observed $3 \mathrm{~h}$ after treatment, after which they dropped to $15 \mu \mathrm{g} \mathrm{ml} \mathrm{m}^{-1}( \pm 2.3)$ by $24 \mathrm{~h}$ post-treatment. Subsequent elimination of injected flumequine (Fig. 5b) proceeded at a slower rate than occurred with the bathadministered drug, with serum levels of $12 \mu \mathrm{g} \mathrm{ml} \mathrm{ml}^{-1}$ $( \pm 2.2)$ and $3 \mu \mathrm{g} \mathrm{ml}^{-1}( \pm 1.4)$ being recorded after 3 and $14 \mathrm{~d}$ respectively.

\section{Effect of feeding on absorption}

The bath treatment of both fed and unfed brown trout in the same bath solution resulted in similar flumequine serum levels being recorded for both groups. Serum levels of $36 \mu \mathrm{g} \mathrm{ml} \mathrm{m}^{-1}$ ( \pm 9.3$)$ were
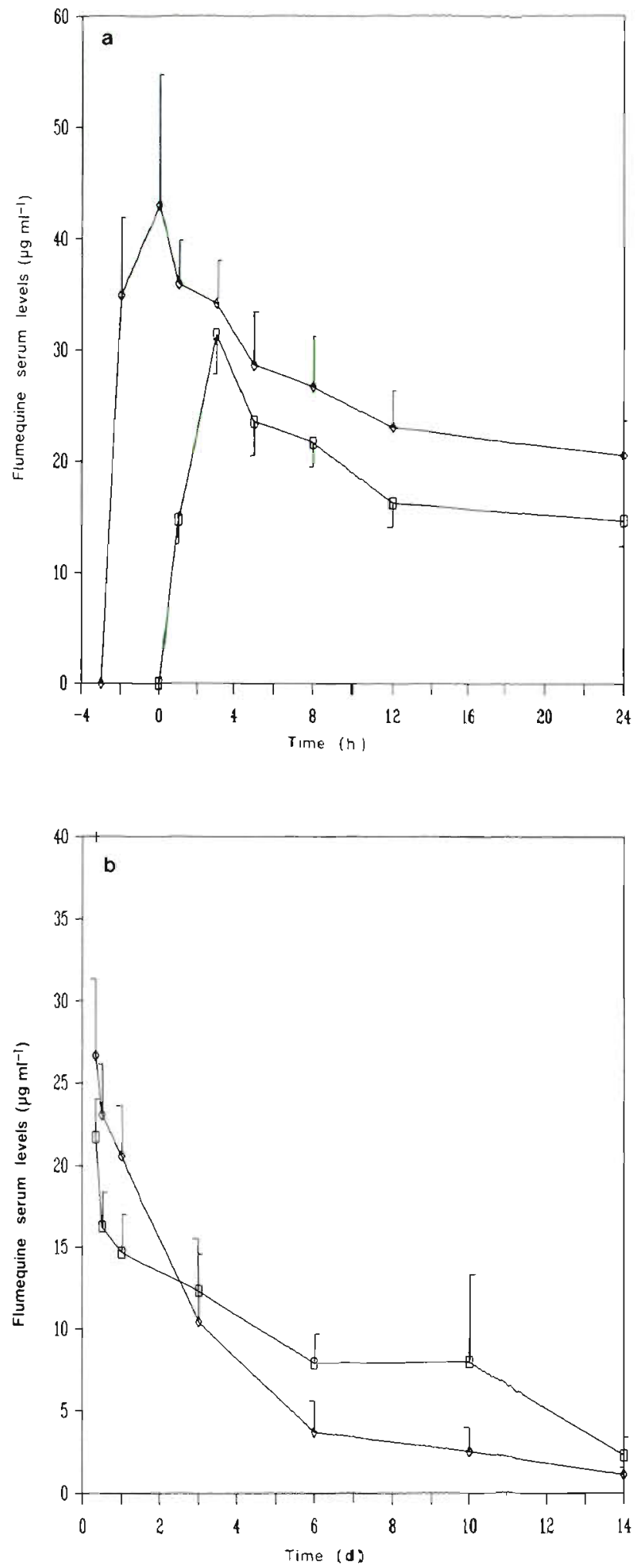

Fig. 5. Salmo trutta. Retention times of flumecruine serum following administration of the drug by bathing and injection. (0) Bath administration of flumequine at $50 \mathrm{ppm}, 11{ }^{\circ} \mathrm{C}$ and $\mathrm{pH}$ 7.0 in distilled water for $3 h_{i}(c)$ intraperitoneal injection of flumequine at $30 \mathrm{mg} \mathrm{kg}^{-1}$ fish. (a) First $24 \mathrm{~h}$ after treatment;

(b) first $14 \mathrm{~d}$ after treatment 
observed in fish that had been fed at $1 \%$ body weight per day for $3 \mathrm{wk}$. The group that recejved no feed showed serum levels of $33 \mathrm{Mg} \mathrm{ml}^{-1}(=4.2)$.

\section{Toxicity of bath-administered flumequine}

The first sign of flumequine toxicity, namely lethargy in the treated fish, became apparent after $1 \mathrm{~h}$ of treatment in a bath containing 50 ppm of the drug at pH 6.5 and $11^{\circ} \mathrm{C}$. At this stage, serum levels of $36 \mu \mathrm{g} \mathrm{ml} \mathrm{m}^{-1}$ $( \pm 9.3)$ were observed All 10 fish removed from the bath at this point recovered within $1 \mathrm{~h}$. The remaining fish lost their equilibrium after $4.5 \mathrm{~h}$ of treatment. Flumequine serum levels of $69 \mu \mathrm{gm} \mathrm{m}^{-1}( \pm 12.6)$ were recorded at ihis point and 9 of the 10 remaining fish regained their equilibrum. within $1 \mathrm{~h}$ of removal from the bath. The remaining tish died.

\section{Bath treatment of salmon suffering from furunculosis}

The administration of a $50 \mathrm{ppr}$ flumequine bath treatment at $\mathrm{pH} 7$ and $11{ }^{\circ} \mathrm{C}$ to Atlantic salmon presmolts undergoing a clinical outbreak of furunculosis yielded serum levels of $34 \mu \mathrm{g} \mathrm{m}^{-1}[ \pm 8.8)$ in the treated group of 200 fish. No rnortalities were observed in this group in the $14 \mathrm{~d}$ following treatment. In the untreated control group of 100 pre-smolts, mortalities of $32 \%$, attributable to Aeromonas salmonicida, wrere observed

In post-mortem exaninations carried out on the surviving fish at $14 \mathrm{~d}$ post-treatment. Aeromonas salmonicida was isolated from 1 individual in the treated group and from 15 individuals in the untreated group. All of the $A$. salmonicida isolates tested showed sensitivity to both flumequine and oxalonic acid.

\section{DISCUSSION}

Bath treatments have found their greatest use in the topical administration of chemicals such as formalin and malachite green to farmed fish (Elerwig 1979). However, the application of antibiofics using baths has also been proposed for furanace (Shimizu \& Takase 1967), erythromycin (Swarz 1982), oxytetracycline (Herwig 1979), nifurprazine (Heruig 1979), and oxolinic acid (Endo et a. 19:3).

The absorption of bath-adminstered flumequine followed a definite pattern irespective of flumequine concentration (Fig. 1). This was manifest in the rapid rate of drug absorption in the initial striges of the treatment $(0.5$ to $1 \mathrm{~h}$ ) and in the subsequent marked decrease in the rate of drug absorption ( I to $5 \mathrm{~h}$ ).

The $\mathrm{pH}$ of the bath solstion exerted a strong influ- ence on the uptake of bath-administered flumequine. In general, as the $\mathrm{pH}$ of the bath solution decreased the amount of flumequine absorbed increased. Temperature also significantly influenced the uptake of flumequine, with good absorption being observed at temperatures above $7^{\circ} \mathrm{C}$. Fortunately such temperatures are most likely to be encountered in field situations during periods when treatments are necessary. Calcium has been reported to bind flumequine in aqueous solutions (Robert Collas, Riker Labs, pers. comm.). This property of calcium may explain the results in Fig. 4 which show reduced absorption of flumequine in the presence of increasing levels of calcium. Considering the effect of temperature, $\mathrm{pH}$, and calcium hardness, good results can be achieved with a $50 \mathrm{ppm}$ bath from 7 lo $15^{\circ} \mathrm{C}$, and pri 6.5 io 7.5 utiuising a naturai water source containing low levels of calcium hardness (ca 50 $\mathrm{mg} \mathrm{l}^{-1}$ ).

As standard oral antibiotic therapy is normally applied for 7 to $10 \mathrm{~d}$ it was felt that flumequine bath administrations must be able to achieve and maintain serum levels greater than the MIC for most susceptible fish pathogens for 10d. Ledo et al. (1987) found the MIC of flumequine against Aeromonas salmonicida to be $<0.075 \mu \mathrm{m} \mathrm{m} \mathrm{m}^{-1}$, against Vibrio anguillarium to be $<0.075$ to $0.3 \mu \mathrm{g} \mathrm{ml}^{-1}$, and against Yersinia ruckeri to be 0.075 to $0.3 \mu \mathrm{g} \mathrm{m}^{-1}$. Fig. $5 \mathrm{a}$ and $\mathrm{b}$ demonstrate that $\mathrm{a}$ flumequine bath administration, which achieved peak serum levels of $43 \mu \mathrm{g} \mathrm{m} \mathrm{m}^{-1}( \pm 11.8)$, maintained serum levels in excess of these MIC values for at least $14 \mathrm{~d}$.

The toxic side effects observed in treated fish fell into 2 categories. In one, the treated fish became lethargic; the lethargy occurred at flumequine serum levels of ca $40 \mu \mathrm{g} \mathrm{ml}^{-1}$. In the other, treated fish lost their equilibrium; this reaction occurred at serum levels of ca 70 $\mu \mathrm{g} \mathrm{mi}{ }^{-1}$

Preliminary field trials with flumequine baths using a natural water source and feeding fish have consistently achieved serum levels in excess of those observed in the laboratory using distilled water (unpubl.). Considering the data resulting from the fed/unfed experiment, it is unlikely that this difference in absorption is a consequence of the fact that the fish in the field trials were feeding. The possibility therefore exists that distilled water has an adverse effect on absorption or that there are other undefined parameters which influence flumequine absorption when natural waterbodies are used for a bath administration.

The efficacy of the bath treatment in preventing mortalities in a stressed group of experimental fish suggests that this method should provide a viable chemotherapeutic method for the administration of flumequine to farmed fish. The achievement of flumequine serum levels in excess of those achieved by the recommended i.p. dose of $30 \mathrm{mg} \mathrm{kg}^{-1}$ fish (Scallan \& 
Smith 1985) suggests that bath administrations of flumequine may also find application as a prophylactic method for the control of furunculosis in farmed salmon. prior to their transfer to seawater. However, the environmental considerations involved in adding antibiotics to farm waters during bath treatments must also be addressed. Because of this, bath treatments may be of limited use until a safe disposal method for the residual antibiotics in baths is developed.

The future use of flumequine will also depend on its efficacy in combating pathogenic bacteria resistant to the quinoline antibiotics. The isolation of strains of Aeromonas salmonicida possessing 2 separate levels of resistance to flumequine and oxolinic acid has been reported (O'Grady et al. 1987). Furunculosis caused by these pathogenic strains was reported to be unaffected by oral oxolinic acid therapy at 3 times the recommended dosage (O'Grady et al. 1987). Research on the efficacy of flumequine bath administrations in controlling epizootics caused by the oxolinic acid resistant strains is in progress.

\section{LITERATURE CITED}

Austin, B., Rayment, J., Alderman, D. J. (1983). Control of furunculosis by oxolinic acid. Aquaculture 31. 101-108

Benothame, A. (1979). Contribution à l'etude de la flumequine. Applications therepeutiques en medicine vetinaire. $\mathrm{Ph}$. D. thesis, Lyon University, France

Brown, D., Blowers, R. (1978). Disc methods of sensitivity testing and other semiquantitative methods. In: Reeves, D. S., Phillips, I., Williams, J. D., Wise, R. (eds.) Laboratory methods in antimicrobial chemotherapy. Churchill Livingstone, Edingburgh, p. 8-30

Chevalier, R., Gerard, J.-P., Michel, C. (1981). Distribution et cinetiques tissulaire de la flumequine chez la truite arc-enciel (Salmo gairdneri, Richardson). Recherce de residus. Rev. Med. vet. 132 (12): 831-837

Edelson, J., Davidson, C., Benziger, D. P. (1977). Quinolone and 'Azoquinolone' antimicrobial agents. Drug. Metab. Rev. 6: 105-148

Endo, T., Ogishima, K, Hayasaka, H., Kaneko, S., Oshima, S. (1973). Application of oxolinic acid as a chemotherapeutic agent against infections diseases in fishes. Bull. Jap. Soc. scient. Fish. 39: 165-171

Franson, M. A., Greenberg, A. E., Rand, M. C., Taras, M. J. (eds.) (1974). Standard methods for the examination of water and wastewater. American Public Health Association, Washington D. C., p. 189-191
Herwig, N. (1979). Handbook of drugs and chemicals used in the treatment of fish diseases. Thomas Books, Springfield, Illinois

Katae, H., Kouno, K., Takase, Y., Miyazaki, H., Hashimoto, M. Shimizu, M. (1979). The evaluation of piromidic acid as an antibiotic in fish: an in vivo and in vitro study. J. Fish Dis. 2: 321-335

Ledo, A., Dopazo, C. P., Romalde, J. L., Toranzo, A. E., Barja, J. L. (1987). Effectiveness of different chemotherapeutic agents for controlling bacterial fish diseases. Bull. Eur. Ass. Fish Path. 7 (1): 20-22

Lemeland, J. F., Roger, J. P. H., Hubert, G. (1981). Les nouvelles quinolones. Rev. Med. (Paris) 22: 121-126

Michel, C., Gerard, J.-P., Fourbet, B., Collas, R., Chevalier, R. (1980). Emploi de la flumquine contre la furunculose des salmonides: essais therapeutiques et perspectives pratiques. Bull. franç. Pisci. 277: 154-162

Neuman, M. (1978). Flumequine. Drugs Today 14: 365-566

O'Grady, P., Palmer, R., Rodger, H., Smith, P. R. (1987). Isolation of Aeromonas salmonicida strains resistant to the quinoline antibiotics. Bull. Eur. Ass. Fish Path. 7 (2): 43-46

Reeves, D. S., Bywater, M. J. (1976). Assay of antimicrobial agents. In: De Louvois, J. (ed.) Selected topics in clinical bacteriology. Bailliere Tindall, London, p. 21-78

Rodgers, C. J., Austin, B. (1983). Oxolinic acid for control of enteric redmouth disease in rainbow trout. Vet. Rec. 112: 83

Rohlfing, S. R., Gerster, J. F., Kvam, D. C. (1976). Bioevaluation of the antibacterial flumequine for urinary tract use. Antimicrob. Agents Chemother 10: 20-24

Rohlfing, S. R., Gerster, J. F., Kvam, D. C. (1977). Bioevaluation of the antibacterial flumequine for enteric use. J. antim. Chemother 3: 615-620

Scallan, A. (1983). Investigations into asymptomatic carriers of furunculosis. Ph. D. thesis, National University of Ireland, Dublin, Ireland

Scallan, A., Smith, P. R. (1985). Control of asymptomatic carriage of Aeromonas salmonicida in Atlantic salmon smolts with flumequine. In: Ellis, A. E. (ed.) Fish and shellfish pathology. Academic Press, London, p. 119-126

Shimizu, M., Takase, Y (1967). A potent chemotherapeutic agent against fish diseases: 6-hydroxymethyl-2-[2-15nitro-2-furyl)vinyllpyridine (P-7138). Bull. Jap. Soc. scient. Fish. 33: 544-554

Steer, C. R., Huby, C. L., Ball, E. T., Wilson, A. M. M., Gray, J. A. (1981). Clinical and laboratory studies with R-802, a new synthetic quinolone, in urinary tract infection. J. antim. Chemother. 7 : 643-648

Swarz, A. (1982). The uptake and distribution of erythromycun phosphate in a drug-surfactant bath with several species of salmonids. M. Sc. thesis, University of Idaho

Ziv, G., Soback, S., Bor, A., Kurtz, B. (1986). Clinical pharmacokinetics of flumequine in calves. J. vet. Pharm. Therap. 9: 171-182 